\title{
SUPERSTITIOUS RITUAL BEHAVIOR IN SPORTS: A COMPARATIVE STUDY AMONG VARIOUS ATHLETES
}

\author{
Ashoke \\ Mukherjee $^{1+}$ \\ Abdul Sarjen \\ Shaikh ${ }^{2}$
}

\author{
${ }^{1,2}$ Department of Physical Education E̊ Sport Science, Vinaya Bhavana \\ Visva-Bharati Santiniketan, West Bengal, India. \\ 'Email:somu03simi@gmail.com Tel: +919064225843 \\ ${ }^{2}$ Email:abdulsarjenshaikh@gmail.com Tel: +919126420396
}

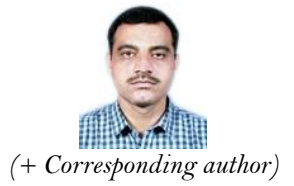

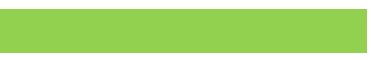

Article History

Received: 27 October 2021 Revised: 30 December 2021 Accepted: 12 January 2022 Published: 21 January 2022

\section{Keywords}

Superstitious behavior

Rituals

Athletes

Sports performance

Superstitions

Effectiveness
The aim of the study was to assess the superstitious ritual behavior of the University level sports persons and to find out that male or female athlete who believes more in superstitions. Eighty-three (83) University level athletes (Male - 44 and Female - 39) of 18 to 25 years from Visva-Bharati University, Santiniketan, India have been selected through purposive random sampling. The Superstitious Ritual Questionnaire (SRQ) framed by Flanagan (2013) has been used to assess the superstitious ritual behavior and its effectiveness on sports performance enhancement. In overall percentage $25.30 \%$ of male athletes and $20.48 \%$ of female athletes are of the opinion that sometimes superstitious ritual behavior is effective in sports performance enhancement. Statistical analysis does not reveal any significant relationship between superstitious ritual behavior (Male: Mean 108.48, SD 22.38; Female: Mean 109.03, SD 24.46) and its effectiveness (Male: Mean 3.23, SD 0.74; Female: Mean 2.80, SD 0.73) in sports performance enhancement for both male $(r=0.263)$ and female $(r=0.140)$ group. As per as the opinion towards the effectiveness of superstitious rituals behavior on sports performance enhancement is concerned the male athletes found to be significantly more superstitious than female athletes $(\mathrm{t}=2.69)$. So it can be concluded that irrespective of male or female mostly all the athletes believes in some sort of superstitious rituals may be to control luck and fear of failure, increase confidence, maintain focus, decreases stress and anxiety etc. at the highest level of sports competitions.

Contribution/Originality: This original research paper's primary contribution is in finding out the fact that mostly all the sports persons believes in some kind of superstitious rituals but scientifically those are not effective in sports performance enhancement except psychological boosting.

\section{INTRODUCTION}

'Superstition' a common term used in mostly all the human society throughout the world from the inception of mankind (Vyse, 1997) basically is a kind of beliefs or faith (Merriam-Webster, 2021) which don't have any scientific evidences (Cambridge Dictionary, 2022) mainly used as defensive attitude against some kind of fear (COBUILD, 2022; Vocabulary.com, 2022) to get success magically in life (Macmillan Dictionary, 2022).

Some common examples of superstition of our social life are: crossing a cat in front of a running car, sneezing in front of someone who is going for some good work are treated as bad luck, number 13 is an unlucky number; on the other hand using same dress by the sports person with which he/she have performed well previously or writing with same lucky pen during the examination etc. are treated as good luck. Such kind of superstitious behavior 
developed among the persons through some religion myths, village folklore, or family beliefs etc. which are illogical or unscientific (Britannica, 2020) but accepted blindly (Webster, 2012).

According to American Psychological Association (2020) and the experts of Comparative Cognition Laboratory (2022) superstitious behavior will be developed in an individual if he/she gets sudden success due to some miracle then he/she will treat it as good luck and continues to repeat same kind of actions for future activities and vice versa.

Findings of different researches have shown that in spite of its mysterious nature (Inglehart, 2002) there is a positive relation between superstitious beliefs, cultural rituals and survival skills (Farasatkhah, 1992) and women and less educated people are more superstitious than men (Emme, 1932; Griffiths \& Bingham, 2005) and superstition decreases with increased age and education (Parida, 1962).

When individuals starts losing control over the activity and possible results (Hunt \& Short, 2006) they search for some favorable outcome magically (Case, Fitness, Cairns, \& Stevenson, 2004) which develops superstitious beliefs among them (Skinner, 1948) and the brain responds on the basis of those beliefs (Rudski, Lischner, \& Albert, 1999). Research have shown that superstitious beliefs help the students and athletes to overcome various stressful situations and enhance their performance (Damisch, Stoberock, \& Mussweiler, 2010) as it lowers the anxiety before any important work (Fader, 2020).

The existence of superstitious beliefs in the form of some unnatural, unscientific and mysterious activities can be found out from old primitive human culture (Jahoda, 1969) and is present in the modern culture also (Newport \& Strausberg, 2001). Sports as a socio-cultural phenomenon (Frey \& Eitzen, 1991) the presence of superstitious behaviors and ritualistic beliefs are quite natural among the sports persons (Obare, 2000).

Entire sporting world individually or by team believes in some sort of superstitious rituals like wearing same number t-shirts (Number 10 jersey in football) by the best player of the team or team hurdles before starting a particular match etc. (Lawrence, 2005; Wargo, 2008). Various forms of superstitious rituals used in sports like team rituals, lucky numbers, lucky charms and clothing rituals (Ofori, Biddle, \& Lavallee, 2013) helps the athletes to reduce their stress and anxiety (Wang, Hernandez, Minor, \& Wei, 2009), boosts confidence and control their emotions (Becker, 1975) and helps them to perform well in difficult situations (Park, 2000).

Actually superstitious behavior acts as "psychological placebo" (Neil, 1980) which helps to cope up with competitive stress and helps in physical performance (Ofori et al., 2013). Though there is no clear cut evidence that the superstitious behavior helps in execution of technical skill, yet the sports persons believes that it has a power to control luck and /or other external factors (Morgan, 1996).

Packing of kit bag, listening music, particular kind of kit to be worn during the game etc. are few common superstitious rituals used by the athletes from long past (Cherrington, 2014). The superstitious behavior or rituals differ on the basis of nature of sports. Use of similar equipment, order of entering the playing arena or their playing position, activities in the dressing room, repetitive rituals and sports personalities etc. are few common superstitions, believes by the sports persons of team sports (Gregory, 1971) and in individual events the superstitions are related with lucky uniform, using of particular articles and equipment etc (Becker, 1975; Gregory \& Petrie, 1972). The most popular and common types of superstitions, believes by the athletes are clothing, manner of dressing, numbers, practices to prevent or cure injury, equipment care and use etc (Becker, 1975).

Top class sports person uses various kinds of superstitious rituals as the higher level of competitive situations and their whole hearted involvement in the competition (Neil, Anderson, \& Shappard, 1981) makes them more anxious and uncertain regarding the success through their performance (Schippers \& Van Lange, 2006). It has been assessed that the superstitious behavior is more prevalent during easiest conditions among the amateur sports persons and during difficult conditions among the expert sports person (Wright \& Erdal, 2009).

As per as superstition of men and women athletes are concerned it has been found that the female athletes are mainly superstitious related to their personal appearance including uniform, hair, specific hair accessories, team 
cheers, hands and social pre-game-night activities whereas the male athletes are more superstitious in to their business practices, equipment, religious practices and repetitive actions (Gregory \& Petrie, 1975). Tahir, Qureshi, and Safi (2018) concluded that as per as superstitious beliefs are concern women and rural people are more superstitious than the male and urban people.

So, it is evident that irrespective of male and female athletes they believe in some short of superstitious rituals. The superstitious rituals are sometimes provides mental strength to perform well. Though there is no such scientific evidence that the superstitious rituals helps in performance enhancement. Then also the sports persons believe in superstitions. By this understanding the present researcher intended to find out male or female University level sports persons who believes more in superstitions.

Aim \& Objectives: The aim of the study was to assess the superstitious ritual behavior of the University level sports persons and to find out that male or female athlete who believes more in superstitions.

\section{MATERIALS \& METHODS}

Participants: Total eighty three (83) University level athletes (Male - 44 and Female - 39) from different sports See Table 1, aged 18 to 25 years from Visva-Bharati University, Santiniketan, India who have at least represented their own district, state or University at the state, national or University (Regional/All India) level sports competition during the last 5 years duration See Table 2 and Figure 1. Purposive random sampling technique has been used for the selection of subjects.

Table 1. Inclusion and exclusion criteria of the participants.

\begin{tabular}{l}
\hline Inclusion Criteria \\
\hline Athletes from different sports from Visva-Bharati University, Santiniketan, India. \\
Age 18 to 25 years male and female. \\
Participated in sports competition during last five years $(2016-2020)$. \\
Level of sports competition: Inter District, Inter State, Intra University, Inter University \\
(Regional/All India), International etc. \\
\hline Exclusion Criteria \\
\hline Athletes not from Visva-Bharati University, Santiniketan, India. \\
Athletes aging $\leq 18$ years or $\geq 25$ years. \\
Athletes who have participated in different sports competitions before 2016. \\
Athletes who are not eligible as per as level of sports competition. \\
\hline
\end{tabular}

Table 2. Participants from different sports.

\begin{tabular}{l|c|c|c}
\hline Sl. No & Sports & Male & Female \\
\hline 1 & Track \& Field & 06 & 08 \\
\hline 2 & Archery & 00 & 03 \\
\hline 3 & Basketball & 05 & 08 \\
\hline 4 & Badminton & 03 & 02 \\
\hline 5 & Cricket & 10 & 00 \\
\hline 6 & Football & 07 & 00 \\
\hline 7 & Gymnastics & 00 & 01 \\
\hline 8 & Handball & 04 & 00 \\
\hline 9 & Volleyball & 05 & 06 \\
\hline 10 & Kabaddi & 02 & 01 \\
\hline 11 & Wushu & 02 & 00 \\
\hline 12 & Yoga & 00 & 10 \\
\hline Total & & 44 & 39 \\
\hline
\end{tabular}



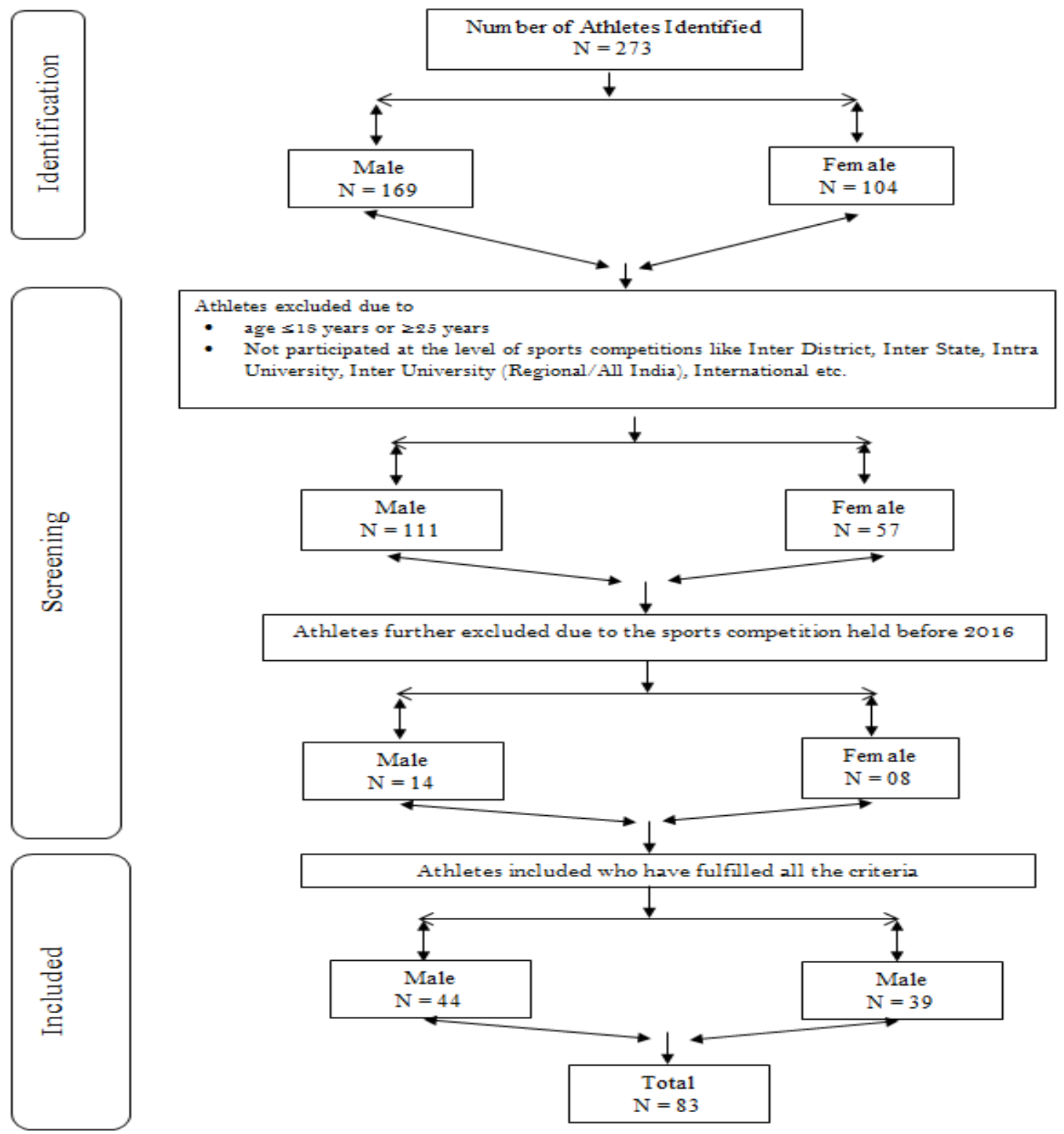

Figure 1. Flow chart of inclusion and exclusion criteria of the participants.

\subsection{Instrumentation and Study Design}

The Superstitious Ritual Questionnaire (SRQ) framed by Flanagan (2013) See Appendix 1 which is a combination of the original Superstitious Ritual Questionnaire (SRQ) of Bleak and Frederick (1998) plus another superstitious questionnaire framed by Flanagan (2013) for his pilot study, was used for the present study. For better understanding the questionnaire has been translated in Bengali. The present questionnaire consist of two parts: first part comprises of 42-item questionnaire divided into seven sections: clothing and appearance, fetish, preparation, game/competition, team ritual, prayer and coach, and second part consist of 11 items. The responses have been recorded in five point Likert Scale using the following scoring system: 1 - Never; 2 - Rarely; 3 - Sometimes; 4 Often; and 5 - All the time. Negatively worded items are scored in reverse from five to one. The total score have been calculated by combining part one and part two. By combining the scores, a total superstitious behavior score was established by summing the number of rituals used by each participant. Furthermore, a single likert-type question was included at the end of the superstitious ritual questionnaires to assess the extent to which participants perceived their superstitious rituals to be effective. These items were rated on a scale ranging from 1 (not at all effective) to 5 (highly effective). The respondents have responded through Google form link. 


\subsection{Statistical Tools Used}

Descriptive statistics has been used in order to get the basic idea on superstitious ritual behavior of both the groups' i.e. male and female athletes. The opinion on effectiveness of superstitious ritual behavior has been converted in percentage for better interpretation of responses. To find out the effectiveness of superstations on sports performance the Pearson Product-Moment Correlation Coefficient Method has been used for both the group. The t-test for independent samples was used to determine the differences in superstitious ritual behavior of both the group. Level of significant has been kept at 0.05 level of confidence. Graphical representation has been given of both the group to show the spread of the distribution of the score.

\section{RESULT}

By summing up the responses made by the individual athlete the total score has been calculated. For better understanding and interpretation of the responses the percentage has been calculated regarding the opinion on the effectiveness of superstitious ritual on sports performance enhancement. The analysis of the data through descriptive statistics, correlation coefficient and t test would provide clear picture about the differences of opinion on superstitious ritual behavior and its effectiveness among the male and female athletes.

Multiple kinds of responses were recorded regarding the effectiveness of superstitious ritual behavior on sports performance enhancement. When we compare within the group negligible number of athletes of both the groups have responded as 'not at all effective' or 'highly effective'; among the female athletes maximum number of athletes is of the opinion that superstitious ritual behavior is 'rarely' or 'sometimes' effective in sports performance enhancement, whereas maximum numbers of male athletes are of the opinion that 'sometimes' or 'often' superstitious ritual behavior is effective in sports performance enhancement See Table 3A and Figure 2. In overall percentage maximum number of athletes of both the group are of the opinion that sometimes superstitious ritual behavior is effective in sports performance enhancement See Table $3 \mathrm{~B}$ and Figure 3.

Table 3. Percentage of responses on effectiveness of superstitious ritual behavior.

\begin{tabular}{l|c|c|c|c|c|c}
\hline \multirow{2}{*}{ Response } & \multicolumn{4}{|c|}{ Within Groups (A) } & \multicolumn{2}{c}{ Overall Percentage (B) } \\
\cline { 2 - 7 } & Male & Percentage & Female & Percentage & Male & Female \\
\hline Not at all effective & OO & $0.00 \%$ & 00 & $0.00 \%$ & $0.00 \%$ & $0.00 \%$ \\
\hline Rarely effective & 07 & $15.91 \%$ & 15 & $38.46 \%$ & $8.43 \%$ & $18.07 \%$ \\
\hline Sometimes effective & 21 & $47.73 \%$ & 17 & $43.59 \%$ & $25.30 \%$ & $20.48 \%$ \\
\hline Often effective & 15 & $34.10 \%$ & 07 & $17.95 \%$ & $18.07 \%$ & $8.43 \%$ \\
\hline Highly effective & 01 & $02.27 \%$ & 00 & $0.00 \%$ & $1.21 \%$ & $0.00 \%$ \\
\hline
\end{tabular}

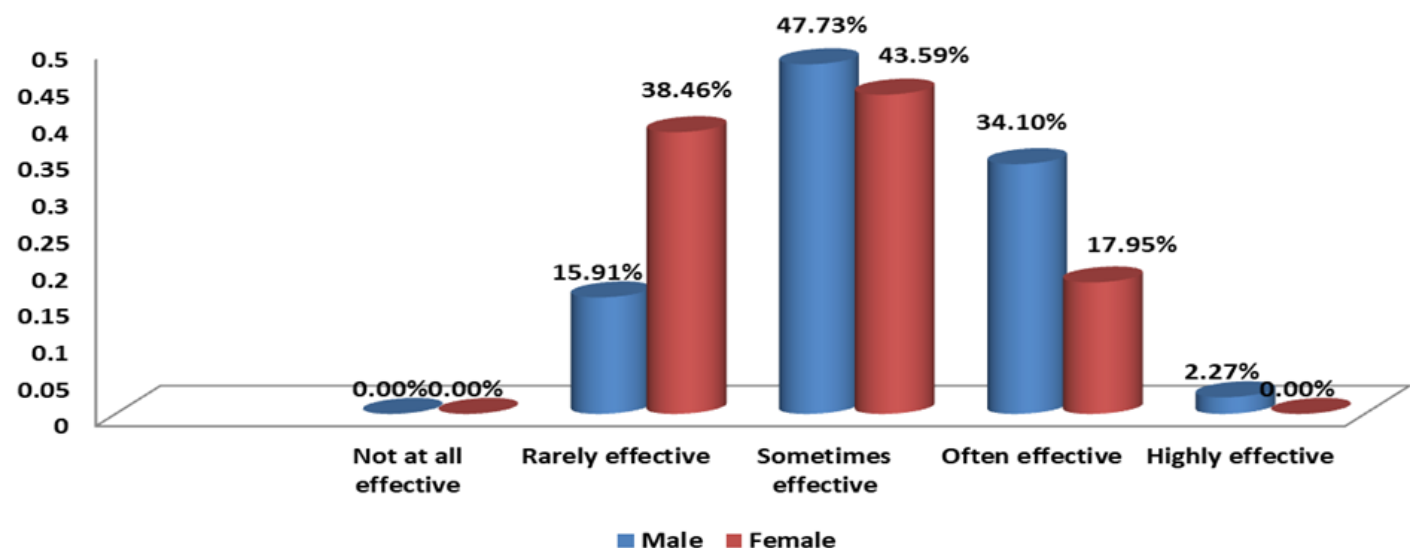

Figure 2. Percentage of responses on effectiveness of superstitious ritual behavior within the groups. 


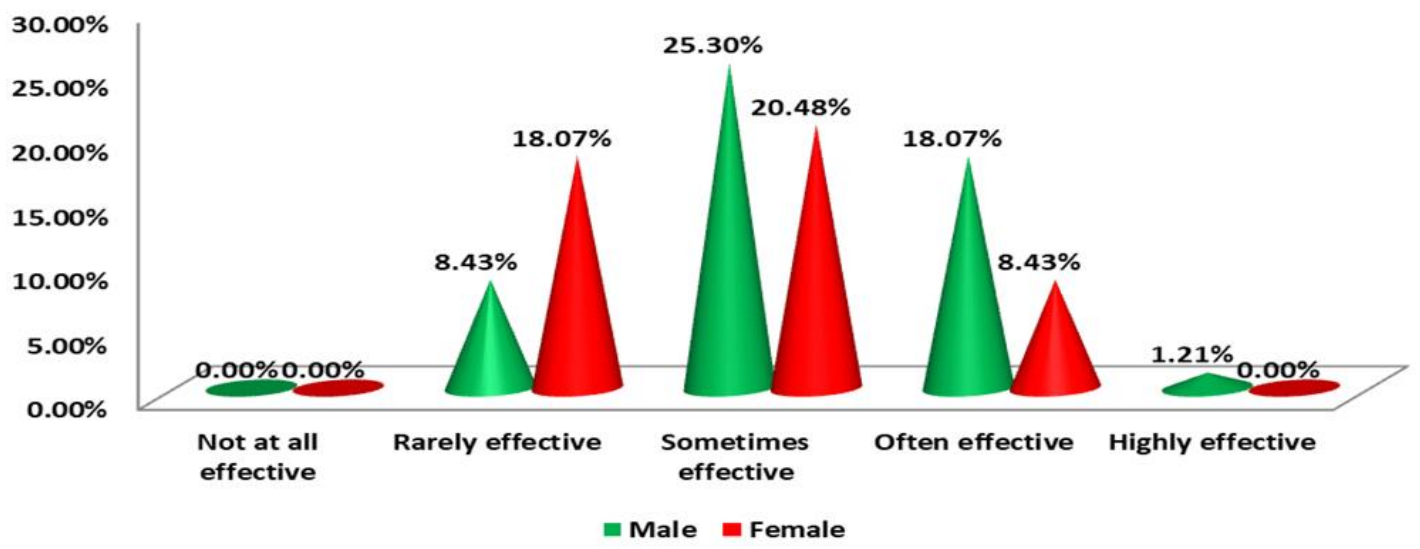

Figure 3. Overall percentage of responses on effectiveness of superstitious ritual behavior.

The descriptive analysis have shown that the female athletes are having more superstitious ritual behavior than the male athletes during the sports competition assuming that it will enhance the sports performance See Table $4 \mathrm{~A}$ and Figure 4. But regarding the effectiveness of superstitious ritual behavior in sports performance enhancement it seems that the male athletes are more superstitious than their female counterpart (See Table 4B and Figure 4). Though statistically there was no significant relationship found between the use of superstitious ritual behavior and its effectiveness in sports performance enhancement See Table $4 \mathrm{C}$ in both the group.

Table 4. Descriptive statistics and correlation coefficient of superstitious ritual behavior and its effectiveness.

\begin{tabular}{l|c|c|c|c|c|c}
\hline \multirow{2}{*}{ S. No. } & \multirow{2}{*}{ Group } & Superstitious Ritual Behavior (A) & \multicolumn{2}{|c|}{ Effectiveness (B) } & \multirow{2}{*}{ Correlation (r) (C) } \\
\cline { 3 - 6 } 1 & Male & Mean & SD & Mean & SD & \multirow{2}{*}{$0.263^{*}$} \\
\hline \multirow{2}{*}{2} & $\mathrm{~N}=44$ & 108.48 & 22.38 & 3.23 & 0.74 & $0.140^{*}$ \\
\hline
\end{tabular}

Note: *Not significant at .05 Level of Confidence. Critical Value of $\mathrm{r}(\mathrm{df}, 42)=0.304$.

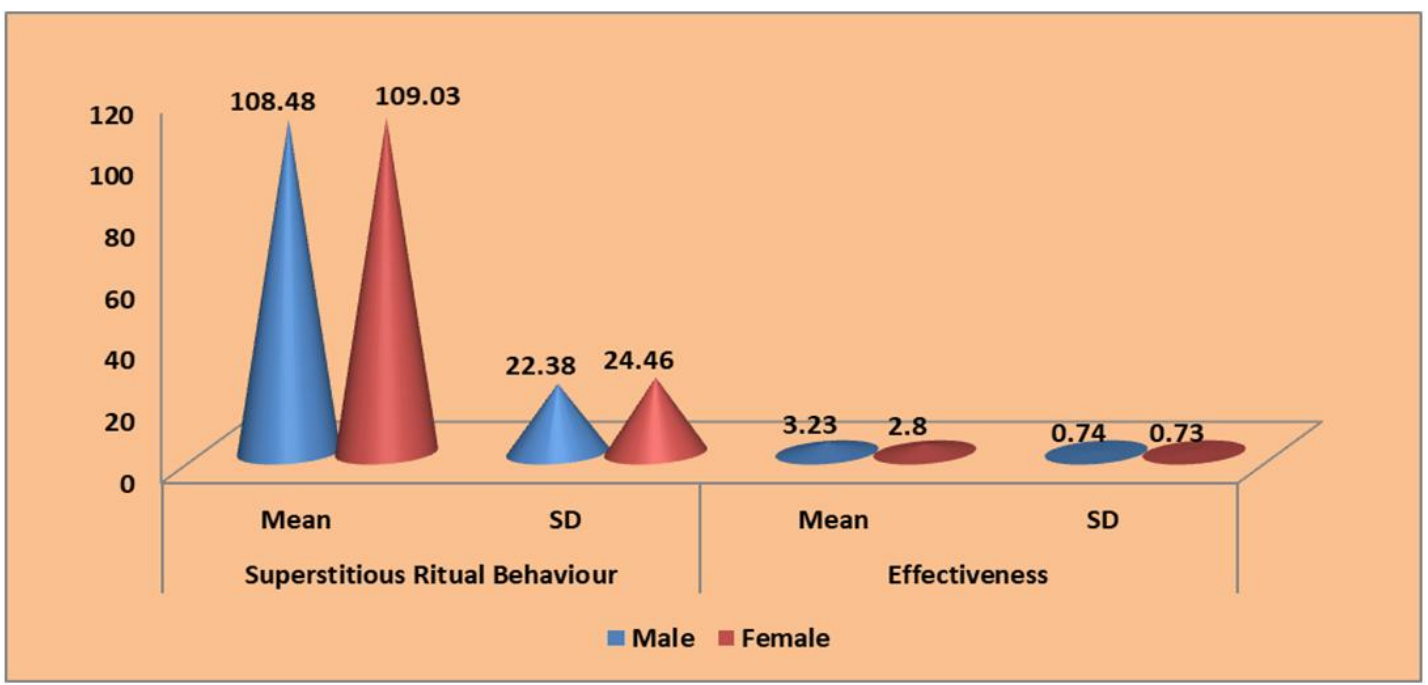

Figure 4. Descriptive statistics of superstitious ritual behavior and its effectiveness.

The comparative analysis done through ' $t$ ' test have revealed the fact that the males as well as female athletes does not differ from each other as per as the use of superstitious ritual behavior during the sports competition is concerned See Table 5A. So, it is clear from the statistical analysis that all the athletes irrespective of male or female believes on some sort of superstitious rituals during the sports competition. 
The comparative analysis on the opinion regarding the effectiveness of superstitious ritual behavior have revealed the fact that the male and female athletes are significantly differ from each other and male athletes are more superstitious regarding the effectiveness of superstitious ritual behavior than female athletes See Table 5 B.

Table 5. Results of t-Test of superstitious ritual behavior and effectiveness.

\begin{tabular}{|c|c|c|c|c|c|c|c|c|c|c|}
\hline \multirow{2}{*}{ Group } & \multirow{2}{*}{$\mathbf{N}$} & \multicolumn{4}{|c|}{ Superstitious Ritual Behavior (A) } & \multicolumn{4}{|c|}{ Effectiveness (B) } & \multirow[t]{2}{*}{ Tab 't' (.05) } \\
\hline & & Mean & MD & df & Cal 't' & Mean & MD & df & Cal't' & \\
\hline Male & 44 & 108.48 & \multirow{2}{*}{0.55} & \multirow{2}{*}{81} & \multirow{2}{*}{0.11} & 3.23 & \multirow{2}{*}{0.43} & \multirow{2}{*}{81} & \multirow{2}{*}{$2.69 *$} & \multirow[t]{2}{*}{1.664} \\
\hline Female & 39 & 109.03 & & & & 2.80 & & & & \\
\hline
\end{tabular}

\section{DISCUSSION}

The statistical analysis of the collected data have revealed the fact that there is very little difference between the male and female sports persons and there is no significant difference between male and female athletes regarding the use of superstitious ritual behavior during the sports competition. But regarding the effectiveness of superstitious ritual behavior on sports performance it has been found that both the groups are significantly differ from each other and the opinion of the male athletes are higher than the females in this regards. As per as the percentage of responses on the effectiveness of superstitious ritual behavior on sports performance is concerned it has been found that higher percentage of male as well as female sports persons are of the opinion that sometimes or often superstitious ritual behavior is effective in sports performance enhancement.

Furthermore male as well as female sports persons are of the opinion that the superstitious ritual behavior is not at all very much effective in the enhancement of sports performance, though low level of insignificant positive relationship found between the superstitious behavior and effectiveness for both the groups.

So it is clear that irrespective of male or female mostly every sports persons believes on superstation but they thinks that the superstitious ritual behavior does not have much effect in the enhancement of sports performance. The research scholar would like to attribute few reasons and facts behind such kind of findings.

Superstitious behavior is actually related with controlling of luck (Bleak \& Frederick, 1998) so the athletes follow some short of superstitious rituals in spite of knowing that there is no scientific evidence that the use of superstitious rituals can enhance the sports performance (Womack, 1992). Athletes thinks that the superstitious ritual behavior actually eliminate the fear of failure (Sagar, Lavallee, \& Spray, 2007; Weinberg \& Gould, 2003) increase confidence (Burke et al., 2002; Womack, 1992) maintain focus (Womack, 1992) decreases stress and anxiety (Bleak \& Frederick, 1998; Brevers, Dan, Noel, \& Nils, 2011; Damisch et al., 2010; McCallum, 1992; Womack, 1992) at the highest level of sports competition (Schippers \& Van Lange, 2006). This may be the reason that irrespective of male and female athletes participated in the present study have responded that they have used some short of superstitious ritual practices before or during the competition and no significant gender difference found on superstitious ritual behavior which is in line with the result of Bleak and Frederick (1998).

But in the case of effectiveness of superstitious ritual on sports performance the maximum participants have responded that sometimes or often it may be effective in increasing sports performance. That is why negligible number of participants has responded in terms of 'not at all effective' and 'highly effective' against the question does superstitious ritual behavior have any effect on sports performance. This is in accordance with the result of the study of Flanagan (2013) where he found very less (6\%) participants responded in favor of effectiveness of superstitious ritual behavior. The findings of Risen and Gilovich (2007) also concluded that superstitious ritual behavior is ineffective, which also supports the findings of the present study.

It has already been discussed that the few athletes things that the superstitious ritual behavior helps in reducing the stress, tension, anxiety etc. up to a certain extent and decrease the fear of failure and relax the athletes (Bleak \& Frederick, 1998; Burke et al., 2002; Damisch et al., 2010). But Flanagan (2013) concluded that there is very weak significant positive relation between superstitious ritual behavior and competitive anxiety level, which may be 
the reason that the irrespective of male or female athlete's response regarding the superstitious ritual behavior and its effectiveness have established insignificant positive relation. This result contradicts the findings of Schippers and Van Lange (2006) who found superstitious ritual behavior had a positive relation with tension and anxiety reduction.

The male sports competition are faster, stronger and involve more athletic and physical ability than the female sports competition, which makes the male sports very tough and the level competiveness becomes very high (Bodenner, 2015). Higher the level of competitiveness the athletes will be more tend towards various kind of superstitious beliefs (Neil et al., 1981) this may be the reason the findings of the present study is showing that the male athletes are more superstitious than the female athletes regarding the effectiveness of superstitious ritual behavior in the enhancement of sports performance. This finding of the present study contradicts the findings of some previous studies (Conklin, 1919; Lundeen \& Caldwell, 1930; Mailer \& Gerhardt, 1933) where it has been found the females are more superstitious than the male.

\section{CONCLUSIONS}

Based on the findings and within the limitations of the present study it can be concluded that irrespective of male or female mostly every sports persons believes in some sort of superstitious rituals but they don't think that superstitious behavior have got much role in the enhancement of their sports performance. Furthermore, the male sports persons are more superstitious than their female counterparts as per as the effectiveness of superstitious ritual behavior on sports performance enhancement is concerned.

Funding: This study received no specific financial support.

Competing Interests: The authors declare that they have no competing interests.

Authors' Contributions: Both authors contributed equally to the conception and design of the study.

Acknowledgement: We would like to thank Visva-Bharati University Sports Board, Santiniketan, India for providing detailed information about the participants. Furthermore, we are grateful to the Department of Physical Education and Sport Science, Visva-Bharati University, India for their constant support and help in conducting the study. Last but not the least we are thankful to all the participants for their honest participation in the study.

\section{REFERENCES}

American Psychological Association. (2020). Superstitious behavior. Retrieved from: https://dictionary.apa.org/superstitiousbehavior.

Becker, J. (1975). Superstition in sport. International Journal of Sport Psychology, 6(3), 148- 152.

Bleak, J., \& Frederick, C. (1998). Superstitious behavior in sport: Levels of effectiveness and determinants of use in three collegiate sports. Journal of Sport Behavior, 21(1), 1-15.

Bodenner, C. (2015). Culture: In why aren't women's sports as big as men's? Your thoughts. The Atlantic. Retrieved From: https://www.theatlantic.com/entertainment/archive/2015/06/women-and-sports-world-cup-soccer/395231/.

Brevers, D., Dan, B., Noel, X., \& Nils, F. (2011). Sport superstition: Mediation of psychological tension on non-professional sportsmen's superstitious rituals. Journal of Sport Behavior, 34(1), 3-24.

Britannica, T. (2020). Editors of encyclopedia superstition. Encyclopedia Britannica. Retrieved from https://www.britannica.com/topic/superstition.

Burke, K. L., Czech, D. R., Knight, J. L., Scott, L. A., Joyner, A. B., Benton, S. G., \& Roughton, H. K. (2002). An exploratory investigation of superstition, personal control, optimism, and pessimism in NCAA division I intercollegiate student athletes. International Sports Journal, 6, 136-145.

Cambridge Dictionary. (2022). Meaning of superstition in English: Superstition. Cambridge University Press. Retrieved from: https://dictionary.cambridge.org/dictionary/english/superstition. 
Case, T. I., Fitness, J., Cairns, D. R., \& Stevenson, R. J. (2004). Coping with uncertainty: Superstitious strategies and secondary control. Journal of Applied Social Psychology, 34(4), 848-871.Available at: https://doi.org/10.1111/j.15591816.2004.tbo2574.x.

Cherrington, J. (2014). It's just superstition I suppose I've always done something on game day': The construction of everyday life on a university basketball team. International Review for the Sociology of Sport, 49(5), 509-525.Available at: https://doi.org/10.1177/1012690212461632.

COBUILD. (2022). Definition of 'superstition': Superstition. HarperCollins Publishers. Retrieved from: https://www.collinsdictionary.com/dictionary/english/superstition.

Comparative Cognition Laboratory. (2022). Superstitious behavior. Retrieved from: https://psychology.uiowa.edu/comparativecognition-laboratory/glossary/superstitious-behavior.

Conklin, E. S. (1919). Superstitious belief and practice among college students. The American Journal of Psychology, 30(1), 83102.Available at: https://doi.org/10.2307/1413662.

Damisch, L., Stoberock, B., \& Mussweiler, T. (2010). Keep your fingers crossed! How superstition improves performance. Psychological Science, 21(7), 1014-1020.Available at: https://doi.org/10.1177/0956797610372631.

Emme, E. E. (1932). Significant counseling relationships on the college campus. Religious Education, 27(2), 145-150.Available at: https://doi.org/10.1080/0034408320270208.

Fader, S. (2020). What is superstitious behavior \& can it be a problem? Retrieved from https://www.betterhelp.com/advice/behavior/what-is-superstitious-behavior-can-it-be-a-problem/.

Farasatkhah, M. (1992). Judging in the sociology of religion: Qian Press. No. 10.

Flanagan, E. (2013). Superstitious ritual in sport and the competitive anxiety response in elite and non-elite athletes. Dublin Business School. Retrieved from: http://hdl.handle.net/10788/1599.

Frey, J. H., \& Eitzen, D. S. (1991). Sport and society. Annual Review of Sociology, 17(1), 503-522.

Gregory, C. J. (1971). Superstitions among male and female intercollegiate athletes and non-athletes of the University of Western Ontario. Unpublished Doctoral Dissertation. University of Western Ontario, Canada.

Gregory, C. J., \& Petrie, B. M. (1972). Superstitions in sport. In: Canadian psycho-motor learning and sports psychology symposium. Paper presented at the Fourth Annual Conference. University of Waterloo.

Gregory, C. J., \& Petrie, B. M. (1975). Superstitions of Canadian intercollegiate athletes: An inter-sport comparison. International Review of Sport Sociology, $10(2)$, 59-68.Available at: https://doi.org/10.1177/101269027501000205.

Griffiths, M. D., \& Bingham, C. A. (2005). Study of superstitious beliefs among bingo players. Journal of Gambling, 13.Available at: https://doi.org/10.4309/jgi.2005.13.7.

Hunt, E., \& Short, S. (2006). Collegiate athletes' perception of adverse ankle taping: A qualitative analysis. Journal of Sport Rehabilitation, 15(4), 280-298.Available at: https://doi.org/10.1123/jsr.15.4.280.

Inglehart, R. (2002). Islam, gender, culture, and democracy. International Journal of Comparative Sociology, 43(3-5), 224228.Available at: https://doi.org/10.1177/002071520204300301.

Jahoda, G. (1969). The psychology of superstition. London: Allan Lane, Penguin Press.

Lawrence, I. (2005). The emergence of'sport and spirituality'in popular culture. The Sport Journal, 8(2), 1-5.

Lundeen, G. E., \& Caldwell, O. W. (1930). A study of unfounded beliefs among high-school seniors. The Journal of Educational Research, 22(4), 257-273.Available at: https://doi.org/10.1080/00220671.1930.10880096.

Macmillan Dictionary. (2022). Superstition: Definitions and synonyms. Macmillan Education Ltd. Retrived from: https://www.macmillandictionary.com/dictionary/british/superstition.

Mailer, J. B., \& Gerhardt, E. L. (1933). Sources of superstitious beliefs. Journal of Educational Research, 26(6), 32 1-343.

McCallum, J. (1992). Green cars, black cats, and lady luck. In S. J. Hoffman (Ed.), Sport and Religion (pp. 203-2 11). Champaign, IL: Human Kinetics Books.

Merriam-Webster. (2021). Superstition. In Merriam-Webster.com dictionary. Retrieved from; https:// $\underline{\text { www.merriam- }}$ webster.com/dictionary/superstition. 
Morgan, L. D. (1996). Annual review of sociology. Focus Groups, 22(1), 129-152 Available at: https://doi.org/10.1146/annurev.soc.22.1.129.

Neil, G. (1980). The place of superstition in sport: The self-fulfilling prophecy. Coaching Review, 3(18), 40-42.

Neil, G., Anderson, B., \& Shappard, W. (1981). Superstitions among male and female athletes of various levels of involvement. Journal of Sport Behavior, 4(3), 137-141.

Newport, F., \& Strausberg, M. (2001). Americans' belief in psychic and paranormal phenomena is up over last decade. Princeton, NJ: Gallup News Service.

Obare, R. S. (2000). Can sports exist without religion? UK: Sheffield University.

Ofori, P. K., Biddle, S., \& Lavallee, D. (2013). The role of superstition among professional footballers in Ghana. Athletic Insight, 14(2), 117-127.

Parida, G. (1962). Superstitions among college students in India. The Journal of Social Psychology, 57(1), 3-10.Available at: https://doi.org/10.1080/00224545.1962.9710898.

Park, J.-K. (2000). Coping strategies used by Korean national athletes. The Sport Psychologist, 14(1), 63-80.Available at: https://doi.org/10.1123/tsp.14.1.63.

Risen, J. L., \& Gilovich, T. (2007). Another look at why people are reluctant to exchange lottery tickets. Journal of Personality and social Psychology, 93(1), 12-22.Available at: https://doi.org/10.1037/0022-3514.93.1.12.

Rudski, J. M., Lischner, M. I., \& Albert, L. M. (1999). Superstitious rule generation is affected by probability and type of outcome. The Psychological Record, 49(2), 245-260.Available at: https://doi.org/10.1007/BFo3395319.

Sagar, S. S., Lavallee, D., \& Spray, C. M. (2007). Why young elite athletes fear failure: Consequences of failure. Journal of Sports Sciences, 25(11), 1171-1184.Available at: https://doi.org/10.1080/02640410601040093.

Schippers, M. C., \& Van Lange, P. A. (2006). The psychological benefits of superstitious rituals in top sport: A study among top sportsmen. Journal of Applied Social Psychology, 36(10), 2532-2553.Available at: https://doi.org/10.1111/j.00219029.2006.00116.x.

Skinner, B. (1948). Superstition in the pigeon. Journal of Experimental Psychology, 38(2), 168-172.

Tahir, T. B., Qureshi, S. F., \& Safi, T. (2018). Superstitions as behavioral control in Pakistan. Pakistan Journal of social Sciences (PJSS), 38(2), 771-782.

Vocabulary.com. (2022). Superstition. Retrieved from: https://www.vocabulary.com/dictionary/superstition.

Vyse, S. A. (1997). Believing in magic: The psychology of superstition. New York: Oxford University Press.

Wang, Y. J., Hernandez, M. D., Minor, M. S., \& Wei, J. (2009). Superstitious beliefs in consumer evaluation of brand logos: Implications for corporate branding strategy. European Journal of Marketing, 46(5), 712-732.Available at: http://dx.doi.org/10.1108/03090561211212485.

Wargo, E. (2008). The many lives of superstition. APS Observer, 21(9), 18-24.

Webster, R. (2012). The encyclopedia of superstitions (Kindle Edition ed.). USA: Llewellyn Publications.

Weinberg, S. R., \& Gould, D. (2003). Foundations of sport and exercise psychology (5th ed.). Champaign, IL: Human Kinetics Books.

Womack, M. (1992). Why athletes need ritual: A study of magic among professional athletes. In Shirl Hoffman (Ed.), Sport and Religion (pp. 191-202). Champaign, IL: Human Kinetics.

Wright, P., \& Erdal, K. (2009). Sport superstition as a function of skill level and task difficulty. Journal of Sport Behavior, 32(2), 187-199.

\section{APPENDEX 1}

Superstitious Ritual Questionnaire (Flanagan, 2013)

Listed below are a variety of rituals athletes may use before or during games (competitions etc.) For each ritual you use, please select below how often you make use of it to help you perform at your sport. Some of the questions may not be relevant to you or your particular sport, if so, simply answer the questions to the best of your ability. 


\section{General Information about the Participants}

Name:

Sports:

Superstitious Ritual (Part 1)
Age:

Gender:

Level of Participation:

\section{A. Clothing and Appearance}

\begin{tabular}{|c|c|c|c|c|c|c|}
\hline S.No. & Question & Never & Rarely & Sometimes & Often & $\begin{array}{l}\text { All the } \\
\text { time }\end{array}$ \\
\hline 1. & $\begin{array}{l}\text { How often do you check your appearance in } \\
\text { the mirror before each game/ competition/ } \\
\text { event? }\end{array}$ & & & & & \\
\hline 2. & $\begin{array}{l}\text { How often do you put good luck markings on } \\
\text { your shoes before your games/ competitions/ } \\
\text { events? }\end{array}$ & & & & & \\
\hline 3. & $\begin{array}{l}\text { How often do you dress well to feel better } \\
\text { prepared for your game/ competition/ event? }\end{array}$ & & & & & \\
\hline 4. & $\begin{array}{l}\text { How often do you wear your tracksuit in the } \\
\text { same way before each game/ competition/ } \\
\text { event? }\end{array}$ & & & & & \\
\hline 5. & $\begin{array}{l}\text { How often do you dress sloppily- to help you } \\
\text { feel better prepared for your game/ } \\
\text { competition/ event? }\end{array}$ & & & & & \\
\hline 6. & $\begin{array}{l}\text { How often do you get your hair cut on the day } \\
\text { of your game/competition/ event? }\end{array}$ & & & & & \\
\hline 7. & $\begin{array}{l}\text { How often do you not shave on the day of your } \\
\text { game/ competition/ event? }\end{array}$ & & & & & \\
\hline 8. & $\begin{array}{l}\text { How often do you take an ice bath on the } \\
\text { morning of your game/Competition/event } \\
\text { day? }\end{array}$ & & & & & \\
\hline 9. & $\begin{array}{l}\text { How often do you paint your face (e.g. black } \\
\text { under eyes or apply sun cream) before your } \\
\text { game/ competition/ event? }\end{array}$ & & & & & \\
\hline 10. & $\begin{array}{l}\text { How often do you eat the same pre-game/ } \\
\text { competition/ event meal on the day? }\end{array}$ & & & & & \\
\hline 11. & $\begin{array}{l}\text { How often do you wear special socks under on } \\
\text { the game/ competition / event days? }\end{array}$ & & & & & \\
\hline
\end{tabular}

\section{B. Fetish}

\begin{tabular}{|c|c|c|c|c|c|c|}
\hline S.No. & Question & Never & Rarely & Sometimes & Often & $\begin{array}{l}\text { All the } \\
\text { time }\end{array}$ \\
\hline 1. & $\begin{array}{l}\text { How often do you wear a lucky item of } \\
\text { clothing on the game/ competition / event } \\
\text { day? }\end{array}$ & & & & & \\
\hline 2. & $\begin{array}{l}\text { How often does a team mascot help you to } \\
\text { motivate in game/ competition / event? }\end{array}$ & & & & & \\
\hline 3. & $\begin{array}{l}\text { How often do you wear a lucky charm on } \\
\text { game/ competition/ event days? }\end{array}$ & & & & & \\
\hline 4. & $\begin{array}{l}\text { How often do you wear a lucky charm so it can } \\
\text { be seen on game / competition / event days? }\end{array}$ & & & & & \\
\hline 5. & $\begin{array}{l}\text { How often do you wear a lucky charm so it } \\
\text { cannot be seen on game / competition/ event } \\
\text { days? }\end{array}$ & & & & & \\
\hline 6. & $\begin{array}{l}\text { How often do you kiss/touch a lucky charm } \\
\text { before your game/ competition / event? }\end{array}$ & & & & & \\
\hline
\end{tabular}


C. Preparation

\begin{tabular}{|c|c|c|c|c|c|c|}
\hline S. No. & Question & Never & Rarely & Sometimes & Often & $\begin{array}{l}\text { All the } \\
\text { time }\end{array}$ \\
\hline 1. & $\begin{array}{l}\text { How often do you tape your body - even if not } \\
\text { injured, before your game/ competition/ event } \\
\text { day? }\end{array}$ & & & & & \\
\hline 2. & $\begin{array}{l}\text { How often do you listen to music during/ before } \\
\text { your warm-up? }\end{array}$ & & & & & \\
\hline 3. & $\begin{array}{l}\text { How often do you snack before the start of your } \\
\text { game/competition/ event? }\end{array}$ & & & & & \\
\hline 4. & $\begin{array}{l}\text { How often do you need silence / seclusion before } \\
\text { your game / competition / event? }\end{array}$ & & & & & \\
\hline 5. & $\begin{array}{l}\text { How often do you have the same person do any } \\
\text { taping job(s) on game/ competition/ event days? }\end{array}$ & & & & & \\
\hline 6. & $\begin{array}{l}\text { How often do you do warm-up for your game/ } \\
\text { competition/ event using the same routine? }\end{array}$ & & & & & \\
\hline
\end{tabular}

\section{Game/ Competition}

\begin{tabular}{|c|c|c|c|c|c|c|}
\hline S. No. & Question & Never & Rarely & Sometimes & Often & $\begin{array}{l}\text { All the } \\
\text { time }\end{array}$ \\
\hline 1. & $\begin{array}{l}\text { How often do you perform a particular cheer or } \\
\text { chant before your game/ competition/ event? }\end{array}$ & & & & & \\
\hline 2. & $\begin{array}{l}\text { How often do you attempt to score the first point } \\
\text { (goal, run etc.), in an effort to improve your luck } \\
\text { for the rest of your game/competition/ event? }\end{array}$ & & & & & \\
\hline 3. & $\begin{array}{l}\text { How often do you high-five/ slap the hand of a } \\
\text { fellow team member who scores during the game/ } \\
\text { competition/ event? }\end{array}$ & & & & & \\
\hline 4. & $\begin{array}{l}\text { How often do you chew gum before/ during the } \\
\text { game/competition/ event? }\end{array}$ & & & & & \\
\hline
\end{tabular}

\section{E. Team Ritual}

\begin{tabular}{l|l|l|l|l|l|l}
\hline S. No. & Question & Never & Rarely & Sometimes & Often & $\begin{array}{l}\text { All the } \\
\text { time }\end{array}$ \\
\hline 1. & $\begin{array}{l}\text { How often do you shake hands/ high-five with } \\
\text { your teammates before /during the game/ } \\
\text { competition/ event? }\end{array}$ & & & & & \\
\hline 2. & $\begin{array}{l}\text { How often does team cheering during the game/ } \\
\text { competition/event help you to preform? }\end{array}$ & & & & & \\
\hline 3. & $\begin{array}{l}\text { How often does a pep talk before the game/ } \\
\text { competition/ event help you feel prepared? }\end{array}$ & & & & \\
\hline 4. & $\begin{array}{l}\text { How often does NO pep talk before the game/ } \\
\text { competition/event help you feel prepared? }\end{array}$ & & & & & \\
\hline
\end{tabular}

\section{F. Prayer}

\begin{tabular}{|c|c|c|c|c|c|c|}
\hline S. No. & Question & Never & Rarely & Sometimes & Often & $\begin{array}{l}\text { All the } \\
\text { time }\end{array}$ \\
\hline 1. & $\begin{array}{l}\text { How often do you pray for success before each } \\
\text { game/competition/ event? }\end{array}$ & & & & & \\
\hline 2. & $\begin{array}{l}\text { How often are you afraid your luck will run out if } \\
\text { you do not pray before each game/ competition/ } \\
\text { event? }\end{array}$ & & & & & \\
\hline 3. & $\begin{array}{l}\text { How often do you pray with your team in the lead } \\
\text { up to/ before your game/ competition/ event? }\end{array}$ & & & & & \\
\hline
\end{tabular}


G. Coach

\begin{tabular}{l|l|l|l|l|l|l}
\hline S. No. & Question & Never & Rarely & Sometimes & Often & $\begin{array}{l}\text { All the } \\
\text { time }\end{array}$ \\
\hline 1. & $\begin{array}{l}\text { How often does your coach make use of } \\
\text { superstitious rituals before games/ competitions/ } \\
\text { events? }\end{array}$ & & & & \\
\hline 2. & $\begin{array}{l}\text { How often does your coach bring a lucky charm to } \\
\text { your game/ competition/ event? }\end{array}$ & & & & & \\
\hline 3. & $\begin{array}{l}\text { How often does your coach encourage prayer/ } \\
\text { meditation before your game/ competition/ event? }\end{array}$ & & & & \\
\hline
\end{tabular}

Superstitious Ritual (Part 2)

\begin{tabular}{|c|c|c|c|c|c|c|}
\hline S. No. & Question & Never & Rarely & Sometimes & Often & $\begin{array}{l}\text { All the } \\
\text { time }\end{array}$ \\
\hline 1. & $\begin{array}{l}\text { How often do you listen to a particular song before } \\
\text { your game/ competition / event? }\end{array}$ & & & & & \\
\hline 2. & $\begin{array}{l}\text { How often do you wear your shoelaces in a } \\
\text { particular way for your game/ competition/ event? }\end{array}$ & & & & & \\
\hline 3. & $\begin{array}{l}\text { How often do you tie your hair in a particular way } \\
\text { for your game/ Competition / event? }\end{array}$ & & & & & \\
\hline 4. & $\begin{array}{l}\text { How often do you put on your kit/ Gear/ Clothing } \\
\text { in a particular Order? }\end{array}$ & & & & & \\
\hline 5. & $\begin{array}{l}\text { How often do you wear the same clothing/ kit to } \\
\text { try continuing a winning streak? }\end{array}$ & & & & & \\
\hline 6. & $\begin{array}{l}\text { How often do you wear a specific colored item of } \\
\text { clothing to help you perform in your game/ } \\
\text { competition/ event? }\end{array}$ & & & & & \\
\hline 7. & $\begin{array}{l}\text { How often do you use a lucky number in relation to } \\
\text { your sport? }\end{array}$ & & & & & \\
\hline 8. & $\begin{array}{l}\text { How often do you touch the ground (as part of a } \\
\text { specific ritual) before or during your game/ } \\
\text { competition/ event? }\end{array}$ & & & & & \\
\hline 9. & $\begin{array}{l}\text { How often do you sit in a particular place in the } \\
\text { changing room before your game/ competition/ } \\
\text { event? }\end{array}$ & & & & & \\
\hline 10. & $\begin{array}{l}\text { How often do you abstain from sexual activity in } \\
\text { the lead up to, or the night before a game/ } \\
\text { competition/ event }\end{array}$ & & & & & \\
\hline 11. & $\begin{array}{l}\text { How often do you NOT allow another player to } \\
\text { use your kit/clothing/ shoes etc. to preserve your } \\
\text { luck? }\end{array}$ & & & & & \\
\hline
\end{tabular}

\section{Effectiveness of Superstitious Rituals:}

Please indicate below how effective you believe your superstitious ritual(s) to be in influencing your performance in game/competition/ event situations

\begin{tabular}{l|l|l|l|l}
\hline Not at all effective & Rarely effective & Sometimes effective & Often effective & Highly effective \\
\hline
\end{tabular}

